\title{
Didactic potential of metaphors used in medical discourse
}

\author{
Katarzyna Karska \\ Medical University of Lublin, Poland
}

Ewelina Prażmo

Maria Curie-Skłodowska University in Lublin, Poland

\begin{abstract}
Specialist languages should be straightforward and unambiguous. In areas such as law, business or medicine precision and to-the-point wording is required. However, in order to facilitate the description of complicated matters, and especially in expert to non-expert communication, unexpected strategies, e.g. metaphorisation, are used. Conceptual metaphor theory, as initially introduced by Lakoff and Johnson (cf. Lakoff \& Johnson, 1980) states that human beings tend to think in metaphors, i.e. we are engaged in constant search of similarities between concepts. This drive for pattern recognition helps us understand the unknown in terms of the familiar, the abstract in terms of the concrete. Most conceptual metaphors are grounded in our physical experience of the world, which means that we draw from this familiar experience while creating metaphorical mappings to the complex, abstract concepts. Controversial as it may seem, the same process applies to understanding professional terms and scientific notions, and as a result the language of law, business, medicine, etc. is heavily metaphorical in nature. In our presentation we focus on medicine alone and analyse a corpus of medical text in search of conceptual metaphors. We claim, that rather than obscuring the message, metaphors actually make it clearer and more precise. They enrich conceptualisation, structure the semantics of the message and serve a number of pragmatic functions, esp. in doctor to patient communication. By choosing a certain metaphor, the message may e.g. be softened in order to lessen the impact it has on the recipient. Moreover, it may be more easily understood if it is built on an adequate conceptual metaphor. Many metaphors used in the medical discourse are based on multimodal representations e.g. descriptions of diseases often invoke the imagery of food including its shape, colour, texture, and smell. Such multimodality of representation (cf. Forceville, 2009 and online) engages a number of cognitive faculties for the construction of a complex conceptualisation and in this way helps us gain better understanding of the concepts described. We claim that conceptual metaphor and esp. pictorial metaphor is a very effective tool used in didactics and its use is perfectly justified in scientific discourses, including the medical discourse. Therefore, in our presentation we analyse pictorial metaphors found in medical discourse and in the field of radiology in particular.
\end{abstract}

Keywords: specialist language, conceptual metaphor, didactics, medicine 


\section{Part 1 - Theoretical considerations}

\section{Conceptual metaphor}

Lakoff \& Johnson's (1980) milestone book and their later works have led to the proliferation of publications related to the conceptual metaphor. They have liberated the metaphor from the constraints of literary studies and therefore it ceased to be perceived as a mere stylistic device. The conceptual metaphor, understood as a way of thinking, is pervasive in every-day language. It helps us structure our thoughts, especially when they are related to complex and abstract concepts, by drawing similarities between the familiar and the unfamiliar. It takes two domains, matched on the basis of their perceived similarity, for a metaphor to come into being. These domains, labelled the source and the target domain, pertain to the concrete and the abstract concept respectively. Our mind's unique ability to immediately recognise patterns and similarities makes it possible for metaphorical mappings to take place. This process occurs at the conceptual level. The model can be represented pictorially in the following way:

\section{mappings}

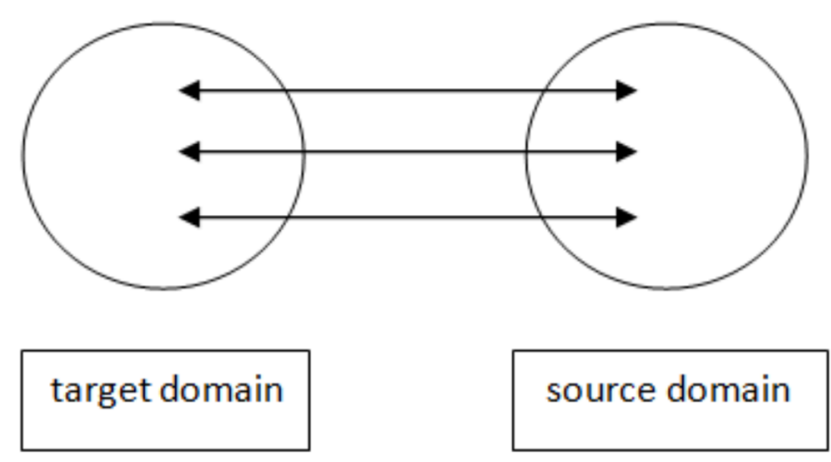

Figure 1: Conceptual Metaphor Model

The target domain is the abstract one and is related to concepts such as time, emotions, human relationships, life, death, morality, and thought. Possible examples of the source domain, i.e. the more concrete domain include: human body, animals, plants, buildings, machines, money, and food. There has to be a degree of similarity between the two domains so that it is possible to draw correspondences between them. The following illustration constitutes a common example of a metaphor: +ECONOMY IS A PLANT+ where possible mappings include +SECTORS ARE BRANCHES +, + PROSPERITY IS FLOWERING+, +PROSPERITY IS GROWTH+, +CRISIS IS WITHERING+ and may be linguistically manifested in expressions such as: blossoming economy, green shoots of economy, flourishing period, GDP withered by $0.5 \%$. Referring to the knowledge of the familiar, concrete, and every-day concepts in order to facilitate understanding of the more complex and abstract ones involves "borrowing" the terminology from the source domain for the description of the target domain.

Although the two domains are conceptual, they manifest themselves in many different ways. The most common and at the same time the most commonly studied are linguistic 
metaphors, however, e.g. Forceville (1996) introduces the concept of pictorial metaphor and Forceville \& Urios-Aparisi (2009) provide a compelling argument for metaphors across gestures, sounds, music, and other modes. What is more, studying the contribution of other types of stimuli (e.g. visual or auditory) on meaning construction has been gaining ground in cognitive linguistics. Such a variety of stimuli has been referred to as multimodality in cognitive linguistics (Pinar Sanz, 2015). Defining a "mode", though, is a difficult task. Says Forceville:

\begin{abstract}
In order to be able to use the concept "mode" for metaphors, it will first be necessary to characterize it more precisely. The instantiations of "mode" just given (pictures, language, music, sound, smell, touch) all pertain to the senses. A convenient strategy would therefore be to equate modes and senses, yielding the pictorial, the sonic, the olfactory, the tactile, and the gustatory mode. However, this would mean lumping together sources of information that are habitually distinguished: while we smell smells, taste tastes, and touch surfaces, we see both written language and pictures, while we hear spoken language, music, and sounds. For one thing, this means that language can be both perceived visually and aurally. I propose there is good reason to do justice to the important differences between these two manners of perception by giving the status of a different mode to "written language" and "spoken language." After all, oral and written text rely on very different conditions of understanding. (Forceville, 2009, online)
\end{abstract}

Thus, metaphors whose domains are rendered in one mode, i.e. they are based on one type of stimulus, (be it language, picture, or music) are referred to as monomodal, whereas "metaphors whose target and source are each represented exclusively or predominantly in different modes" (Forceville 2006, p. 384) are multimodal. The interest in the interplay between different modes of communication is not new, though. The relevance of extra-linguistic factors such as the tone of voice, intonation pattern, gesture accompanying speech, as well as facial expression and body language in general, has been present in the fields of psychology and semiotics, to name just the two. For instance, Kita (2009) analyses cultural differences in gesture interpretation, esp. in reference to the metaphorical aspect of iconic gestures. Duncan et al. (2007) offers a view on the essential role of gesture in dynamic language creation and treats gesture as a part of language, rather than extra-linguistic phenomenon. McNeil (1992) goes a step further and postulates that gesture is an integral part of our cognition and has implications on the way we think. This is also found in Goldin-Meadow (2003) and supported with experimental data.

The metaphors that we analyse in the present paper operate, as if, across two theories: Lakoff and Johnson's conceptual metaphor and Forceville's pictorial metaphor. We try to bring these two theories together in order to provide an exhaustive analysis of the problem. Lakoff and Johnson's conceptual metaphor theory is pivotal for our research. Thus, we accept that:

The metaphor is not just a matter of language, but of thought and reason. The language is secondary. The mapping is primary, in that it sanctions the use of source domain language and inference patterns for target domain concepts. The mapping is conventional, that is, it is a fixed part of our conceptual system, one of our conventional ways of conceptualizing love relationships. This view of metaphor is thoroughly at odds with the view that metaphors are just linguistic expressions. (Lakoff 1992, online) 
As stated above, metaphor is the conceptual layer underlying language, picture, or other modes, which are just surface representations of concepts. We build our argumentation on the structure of Lakoff and Johnson's two-domain model and the terminology that we employ is in line with theirs. However, conceptual metaphor theory as proposed by Lakoff and Johnson aims to show the conceptual structure underlying mainly the linguistic structure. This is insufficient for our research. Forceville's pictorial metaphor, on the other hand, deals exclusively with visual inputs, which is also too limiting, even though Forceville (1996) refers to Black's (1954; 1979) interactional theory of metaphor and claims that:

\begin{abstract}
The cognitivist paradigm insists that verbal metaphors are manifestations rather than reduplications of thought, and thereby forcefully suggests that thought can give rise to nonverbal or multimodal metaphor. However, the cognitivist paradigm hitherto largely disregards the non-verbal. Examination of non-verbal representations should help further substantiate (or cast doubt upon) elements of the already extensive body of research based on verbal representations of metaphor. (Forceville 2007, online)
\end{abstract}

For these reasons, we propose a unified view in which conceptual metaphor theory, coupled with pictorial metaphor theory, provides a new tool for analysis. We claim that although the final outcome is linguistic, the processes that lead to its creation are of different nature. Metaphors used in medical discourse are constructed on the basis of visual input. This primary visual input (microscopic images, radiological data, visual examination of patient's symptoms, etc.) undergoes a number of cognitive processes, the most important of which is pattern recognition and our ability to automatically notice similarities between concepts and link the new income to the information already stored in our memory (Rizutto, 2001). Then, such synthesised primary input is converted into secondary mental imagery. The last stage is the conversion of the secondary mental image into resultant linguistic expression. Thus, we "translate" a vague, mysterious medical image into a familiar one, which we eventually describe in metaphorical terms. The whole process is represented in the diagram below:

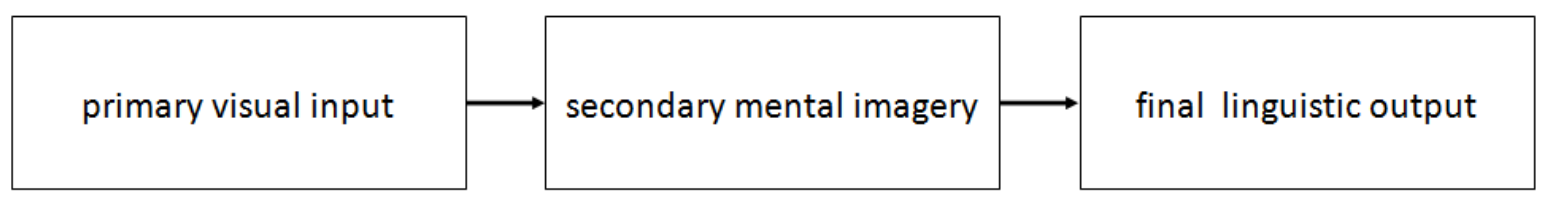

Figure 2: Creation of a metaphorical expression

We will employ the above diagram in order to analyse a number of selected metaphors in the analytical part of the paper. It needs to be emphasised, however, that the metaphors under analysis are indeed conceptual, but not pictorial in Forceville's terms. Visual, i.e. pictorial input is reconceptualised into analogous mental representation involving familiar imagery and then expressed linguistically. Thus, we propose a new notion of multiconceptual metaphor for a metaphor which arises out of the visual input, is synthesised in the conceptual system and results in the linguistic output. 
The diagram illustrates the path that a conceptualiser has to go through in order to arrive at the linguistic result. In other words, in the didactic process, it represents the teacher's perspective. Primary visual input is scanned in the search for familiar analogies and yields a metaphorical result which surfaces in language. However, where the teacher's role ends, the learner's role begins. Thus, the learner has to "decode" the metaphor by visualising the image created in language and then apply the familiar image to the unfamiliar data. In the following part we investigate advantages of this seemingly complicated process.

\section{Metaphor in specialist discourse and teaching}

Before the advent of the conceptual metaphor, metaphors used to be ignored by serious linguists and thinkers. Say Lakoff and Johnson:

\footnotetext{
Literal language, assumed to be mutually exclusive with metaphor, has been taken to be the real stuff of philosophy, the domain where issues of meaning and truth arise and can be dealt with. At best, metaphor is treated as if it were always the result of some operations performed upon the literal meaning of the utterance. (Lakoff \& Johnson 1980b, p. 453)
}

However, the new theory resulted in the change of attitudes. Conceptual metaphor has become recognised and appreciated as both explanatory and constitutive mechanism in scientific discourses. Its use in specialist discourse has been approached from a number of perspectives. Zawisławska (2011) introduces the metaphor in scientific discourse, especially in natural sciences. Sontag $(1978 ; 1988)$ investigates the importance of a careful choice of metaphors in medical discourse and its consequences on social perception of diseases. Also Tajer (2013) discusses how disease and other abstract medicine-related concepts are structured metaphorically. 2015 saw the publication of Herrmann and Sardinha's collection of ten articles investigating the use of metaphor across specialist domains such as biology, psychology, sports, and the penal system. Herrmann (2013) also provides a detailed analysis of the metaphor in academic discourse. For metaphors in newspapers see e.g. Krennmayr (2011).

The role of metaphors in didactics cannot be overestimated. It has been recognised in many specialist areas such as biology. Kashkan et al. (2015) discuss the usefulness of metaphors in teaching biology and medicine in pre-university programs for international students. Kanthan and Mills (online) investigate the importance of metaphors, analogies, and similes in teaching pathology. They proved that using these types of figurative language not only made the learning process more effective, but also "the unexpected impact of creating visual metaphors had a unique potential for improving recall of information". More on metaphors in pathology is found in e.g. Bewtra (1996), Kumar \& Kumar (1994), Batistatou et al. (2000). Using "alimentary metaphors" in the general context of teaching medicine is discussed in Hunter (1998). Numerous examples of analogies found in metaphorical descriptions in medical texts are provided by Pena and de Souza Andrade-Filho (2001; 2010). They make use of Lakoff \& Johnson's (1980) terminology related to conceptual metaphors while describing knowledge already possessed by the learner as "the source" and knowledge to be achieved as "the target". They recognise that similarities, on which metaphors are based, "are important in naming, 
categorizing and classifying, and play a role as learning and memorizing tools". Consequently, they are also used in creating medical nomenclature. Lakhtakia (2014) describes the use of food imagery in medical learning. Terry and Hanchard (1979) investigate the use of culinary terms in gastrology. Milam et al. (2015) study culinary metaphors in dermatology referring to such aspects of food as its colour (port wine stain, café au-lait molecules), texture (peau d'orange skin), and smell (grape-like scent). Also, Wynia (1995) gives an interesting overview of the selection of culinary metaphors used in medical discourse classifying them into thematic categories. We found there e.g. pizza-pie retina, sunflower cataracts and cauliflower ear. For "food signs" (such as: apple core lesion, berry aneurysm pear shaped bladder or sausage digit) in radiology consult Roche et al. (2002). Masukume (2016) presents an overview of food analogies used to describe microscopic images of cells. He stresses the didactic value of such metaphors, as they help memorise shapes necessary for the recognition of signs and make the diagnosis more effective. He enumerates e.g.: coffee bean nuclei, doughnut cell, oat cell carcinoma, popcorn cell, herringbone pattern, grape bunches, fried egg nuclei, tart cell, banana shaped gametocyte, banana bodies, drumstick appendage, bite cell, as well as salt and pepper chromatin, imagery which bear clear visual similarity to foods used in metaphors.

The role of metaphors as didactic tools is essential. However, similarly to conceptual metaphor in medical and other specialist discourses in general, didactic metaphor may be a mixed blessing. On the one hand, metaphors facilitate our understanding of the world and complex problems related to specialist areas. On the other, the choice of metaphors has overarching consequences. A hastily coined metaphor may not only inhibit a successful doctorpatient communication (Carter, 1989), but also deform the data in teaching. Masukume \& Zumla (2015) put emphasis on the increasing use of standardised medical textbooks, written in English and by British authors, in Africa. British terminology and especially the choice of metaphors which may indeed facilitate the task of learning and memorising among some students, is inaccessible for students from different cultures. Teaching with the use of metaphors which are not "locally or culturally relevant", the authors say, should be reconsidered, or a set of standard, culturally-neutral metaphors should be collected and used in specialised textbooks instead. Nonetheless, undoubtedly:

\footnotetext{
Metaphors relating to familiar analogous items make recognition easier in anticipation of the clinical counterpart when encountered in medical practice and serve as teaching aids, enhancing memory retention for medical students, nurses and doctors. (Masukume \& Zumla, 2012, p. 1)
}

The same concern was raised as early as in 1992 by Ahmed et al. whose research showed "that the vast majority of medical students and young resident doctors are not familiar with many of the European foods, fruits and beverages that are commonly used in medical textbooks to describe disease conditions".

Spiro et al. (1989) warn against oversimplification of constructing complex concepts using single metaphors and analogies. They claim that many misconceptions held by medical students may arise from relying on single analogies rather than multiple ones. They provide examples from the biomedical field to prove their point and conclude "that analogies must be used with 
great caution. Even when they are used judiciously to initiate learners into a difficult subject area with appropriate caveats about their limitations, reduction of the topic domain to the source domain appears to be a too common occurrence" (Spiro et al., 1989, p. 18).

Regardless of the occasional problems they may cause, the role of metaphors in didactics has been widely recognised. Carter \& Pitcher (2010) discuss the role of similarity as well as dissimilarity between domains in metaphorical comparisons. They claim that metaphors used in teaching sciences enhance student engagement, increase student analytic and syntactic skills, and very often provide the language for scientific discussion. They also second Lakoff \& Johnson (1980) view of a metaphor as a conceptual phenomenon:

\begin{abstract}
When metaphors are used in science they are part of a way of thinking; they function as structure maps between two different, complex systems. Thus it is not the nouns of the metaphor (e.g. 'water') but the inherent verbs (e.g. 'flows') that convey the most significant meaning. (Carter \& Pitcher, 2010, p. 581)
\end{abstract}

Mouraz et al. (2013) investigates the role of metaphor in higher education, esp. in teacherstudent communication and the transfer of knowledge. The use of metaphors as a teaching resource:

\begin{abstract}
(...) is justified because teaching is also translating knowledge to make it accessible to students and metaphors serve this purpose well. (...) From the perspective of students, this justification finds its correlation in the effectiveness of pedagogical mediation of metaphors, which mobilizes motivation, better and faster understanding as appropriate indicators of their demonstration. (...) The use of metaphors does not relieve students from an effort to understand, requiring an active attitude of interpretation. Metaphors' uses require listeners to reflect both on cultural context and in a critical dimension. (Mouraz et al., 2013, pp. 105-
\end{abstract} 106)

Littlemore \& Low (2006) stress the importance of metaphorical thinking for foreign language learning and claim that figurative thinking is indispensable for reasoning in general. "Metaphorical competence", i.e. being fluent in using and recognising metaphors can be taught, and this is also supported by Bobrova \& Lantolf (2012). Canziani (2016) proves that introducing cognitive linguistics approach to metaphor leads to more productive teaching in medical education.

Skorczynska (2013) provides an overview of metaphors used in educational contexts, focusing mainly on oral interaction, lectures and presentations. She recognises the fact, that "metaphor has for long been used to successfully facilitate education, fulfilling a number of functions such as creating new perspectives, enabling categorization or aiding memorization" (Skorczynska, 2013, p. 2345). Apart from the explanatory function, "the use of metaphoric analogies has been pointed out as an essential aspect of academic discourse and practice, especially in the creation of theories" (Skorczynska, 2013, p. 2345). 


\title{
Methodology and data
}

In the present paper we focus on the didactic potential of metaphors used in medical discourse, paying special attention to pictorial metaphors which make the learning process more effective.

We make use of numerous examples found in specialised literature listed in references, as well as dedicated online resources such as foodmedicaleponyms.blogspot.com

Due to the limitations of space we restrict the scope of data to pictorial metaphors from the "culinary" domain. However, we also briefly enumerate other metaphors, pictorial or otherwise, commonly used in medical discourse as well as metaphors which, due to the graphic imagery that they evoke, serve as effective teaching aids.

\section{Part II - Data analysis}

\section{Selected conceptual metaphors in medical discourse}

+HEALTH IS UP, ILLNESS IS DOWN+

One of the most basic metaphors underlying numerous expressions found in medical discourse is an orientational metaphor based on UP-DOWN image schema. Orientational metaphor:

\begin{abstract}
does not structure one concept in terms of another, but instead organizes a whole system of concepts with respect to one another. We call them "orientational" metaphors because most of them have to do with spatial orientation: UP-DOWN, FRONT-BACK, ON-OFF, DEEP-SHALLOW, CENTRAL-PERIPHERAL. These spatial orientations arise from the facts that we have bodies of the sort we have and that they function as they do in our physical environment. (Lakoff \& Johnson 1980b, pp. 461-462)
\end{abstract}

It can be represented as +HEALTH IS UP, ILLNESS IS DOWN+ where being "up" is associated with upright posture of a healthy individual and "down" with a stooping posture or lying down. This metaphor finds its reflection in numerous fully conventionalised expressions such as to fall ill, to feel down, to feel low, to go down with a flu, to sink into a coma, to succumb to an illness as well as to be in top condition, to bounce back, to be back on one's feet. This metaphor is inextricably linked with +GOOD IS UP, BAD IS DOWN+ metaphor which even strengthens the negative connotations already present in the expressions above.

+DISEASE IS A PHYSICAL OBJECT+

One of the main conceptual metaphor mechanisms is presenting the abstract in terms of the concrete. Not surprisingly we find expressions built on +DISEASE IS A PHYSICAL OBJECT+ metaphor which, as if, reifies a disease, which is an exceptionally abstract phenomenon. A disease does not exist independently of the patient, and can only be characterised as an abnormal condition of the patient's body, a set of symptoms that the patient exhibits and possibly the pathogens that cause it. In order to facilitate our conceptualisation of this abstract 
phenomenon, expressions referring to concrete, physical objects are used. First and foremost we can have or get diseases, also carry, pass on, spread or transmit them.

+DISEASE IS AN ANIMATE OBJECT+

Apart from being reified, diseases can also be presented in animated or even personified ways. We can catch a disease as if it were a living, or at least moving object. A disease may be metaphorically represented as a dangerous animal devouring, or eating us away. They attack us, are lurking in our DNA or running in families. They can be described as treacherous, insidious, tricky, merciless, cruel, ruthless, evil, aggressive, malignant and benign to mention just a few of human characteristics ascribed to the disease based on those metaphors.

Describing the abstract in terms of the concrete and the unfamiliar in terms of the familiar is used in order to make understanding the problem easier. The disease is conceptualised as a living, moving creature possessing animal or human-like features. At the same time, we make use of our embodied experience in order to leave no doubts about the status of the disease as an abnormal and "lowly" creature. These are the relatively basic strategies which enable us to comprehend an otherwise elusive concept, but among the metaphors in medical discourse we find much more elaborate scenarios with multiple mappings. Among them, we find for instance:

(i) +MEDICINE IS A GARAGE+ metaphor, which gives rise to mappings such as: +DOCTOR IS A MECHANIC+, +PATIENT IS A CAR+, +HEART IS A PUMP+ and they, in turn, are expressed linguistically in e.g. heart valve, to fix a problem, broken part.

(ii) +MEDICINE IS ART+ in which we find mappings such as +DOCTOR IS AN ARTIST+, +PATIENT IS A PIECE OF ART+, expressed linguistically in e.g. the art of medicine, to perform an operation.

(iii) +MEDICINE IS A CONSTRUCTION SITE+ whose mappings include: +DOCTOR IS A BUILDER+, + HUMAN BODY IS A BUILDING SITE+, +DOCTOR IS A PLUMBER+, +CORONARY ARTERY DISEASE IS CLOGGED PIPES+ manifested in expressions such as: cell wall, palisade cells, duplex DNA, and DNA library.

(iv) +MEDICINE IS AGRICULTURE+ metaphor with mappings such as: +DOCTOR IS A FARMER+, +PATIENT IS A CULTIVATED FIELD+, +DISEASE IS INFESTATION+ found in: bone marrow harvest, bone marrow graft, tumour seeding, sickle cell, oat cell carcinoma, radiation seeds, bone marrow transplant, stem cell, and dorsal root ganglion cell.

(v) +MEDICINE IS A BUSINESS+ where: +DOCTOR IS A BUSINESSMAN+, +PATIENT IS A CUSTOMER+, +DRUGS ARE GOODS+ as expressed in: free health care, paid services, special package, health coverage (Slumasy, 1993).

(vi) +MEDICINE IS A JUDICIAL SYSTEM+, mappings: +DOCTOR IS A DETECTIVE+, +MEDICAL DATA IS EVIDENCE+, +DISEASE IS A SUSPECT/CRIMINAL+. +DIAGNOSIS IS A JUDGEMENT+, linguistic manifestations: mysterious disease, molecular sleuthing, diagnostic clue, chemical footprinting, a physician may suspect hairy cell leukemia, cancer surveillance, circumstantial evidence of cancer, culprit coronary lesion, accused of giving cerebral postpartum angiopathy, vessels interrogated, testimony to the safeguards, data can testify, 
incriminating evidence, verdict on DDT, jury, exonerate it as a pathogen, incriminates as a causes of aplastic changes.

(vi) +MEDICINE IS WAR+, mappings: +DOCTOR IS A SOLDIER/GENERAL/ALLY+, +PATIENT IS A CIVILIAN/SOLDIER/TERRITORY/ENEMY+, +DISEASE IS AN ENEMY/KILLER+, +DRUGS ARE WEAPONS/AMMUNITION+, expressions: to battle cancer, to fight infections, to combat diseases, big gun antibiotics, an outbreak of disease, an invasion of cancer cells, magic bullet (an ideal drug), flare-up of a disease.

(vii) + MEDICINE IS GEOGRAPHY+ and + HUMAN BODY IS THE GLOBE+, found in expressions such as: vascular lake, vascular waterfall, metastatic cascade, carpal tunnel, ciliary valley.

In some of the metaphorical scenarios enumerated above, the perceived similarity between the two domains is based on their visual aspect. Nonetheless, metaphors which have gained exceptional popularity in the field of medical didactics, and esp. in radiology are the "culinary" metaphors. They will be discussed separately in the following section of the article.

\section{Multiconceptual metaphors in radiology}

The importance of pictorial metaphors is especially transparent in a field of radiology which is inherently based on analysing and describing visual materials. The employment of pictorial metaphors is highly justified due to a number of reasons. Radiology as a very dynamically developing medical discipline requires effective learning techniques, and mnemotechniques based on recognising similarities and analogies between images can be very helpful. These pictorial metaphors are used in radiology to name and help memorize things visible on diagnostic images, so that they are clear not only to other radiologists but also to other physicians (Baker, 2014). Metaphor as a learning tool creates connection between the new and the familiar; to facilitate this connection metaphors usually reach beyond the sphere of medicine (Baker \& Partyka, 2012).

\footnotetext{
How do we learn in radiology? We know that the pictorial patterns we observe with any imaging technique reflect anatomy but do not perfectly reproduce it. Intrinsic to any energy source that produces an image are accentuations and obscurations that must be taken into account. Therefore, to help us come to terms with these limitations, we seek associations from reference images that are common to our experience but outside the realm of anatomy. (Baker \& Partyka, 2012, p. 236)
}

The use of metaphors in medical didactics can be also treated as an enhancement technique, as metaphors boost attention and sensitivity to sign and pattern schemas which could otherwise be easily missed. Baker \& Partyka (2012) provide a convincing argument for the importance of metaphors in radiology, comparing the numbers of metaphors found in radiology and other medical fields. They find that radiology is the only field in which the metaphoric expressions outnumber eponymous ones. They provide a table with numerous examples worth including here in its entirety: 
Table 1: Examples of Metaphoric and Eponymous Signs in Radiology (Baker \& Partyka, 2012, p. 238)

\begin{tabular}{|c|c|c|}
\hline anatomy & metaphoric & eponymous \\
\hline gastrointestinal & $\begin{array}{l}\text { bird's beak sign, corkscrew sign, } \\
\text { Doge's cap sign, Phrygian cap sign, } \\
\text { football sign, Mercedes-Benz sign, } \\
\text { apple core lesion, epicenter sign }\end{array}$ & $\begin{array}{l}\text { Rigler sign, Schatzki ring, Carman } \\
\text { meniscus sign }\end{array}$ \\
\hline musculoskeletal & $\begin{array}{l}\text { blade-of-grass sign, celery stalk sign, } \\
\text { picture frame sign, pencil-in-cup } \\
\text { sign, rugger jersey sign, salt-and- } \\
\text { pepper skull, sandwich vertebra, } \\
\text { shepherd's crook sign, gull wing } \\
\text { sign, inverted Napoleon hat sign }\end{array}$ & $\begin{array}{l}\text { Wimberger sign, Hill-Sachs lesion, } \\
\text { Hawkins sign, Codman triangle, } \\
\text { Haglund deformity }\end{array}$ \\
\hline thoracic & $\begin{array}{l}\text { boot-shaped heart sign, egg-on-a- } \\
\text { string sign, finger-in-glove sign, } \\
\text { halo sign, Luftsichel sign, signet ring } \\
\text { sign, snowman sign, tree-in-bud } \\
\text { sign, sail sign }\end{array}$ & $\begin{array}{l}\text { Sign of Golden, Westermark sign, } \\
\text { Hampton hump }\end{array}$ \\
\hline genitourinary & $\begin{array}{l}\text { cobra head sign, drooping lily sign, } \\
\text { ball-on-tee sign, keyhole sign, } \\
\text { lobster claw sign, spaghetti sign, } \\
\text { fish-hook ureter, comet sign, bear } \\
\text { paw sign, balloon-on-a-string sign }\end{array}$ & Bergman coiled catheter sign \\
\hline
\end{tabular}

\section{However,}

The proliferation of metaphoric signs in radiology does not mean that all of them will resonate equally well with earners. Neuroscientific research has shown that emotions have a critical and inseparable impact on cognition (Eviatar \& Just, 2006). To be successful, a metaphor must establish a connection that stimulates vibrant emotional reaction as the reader or viewer becomes aware of its freshness and thereby its power to instruct. Thus, the reference must not be so obscure that its original meaning is not immediately recognizable. Also, the content of a radiologic finding and the subject alluded to should bring to mind similar scenarios, even though they emanate from different epistemologic systems. (...) Metaphors are grounded in experience. The strength and relevance of a metaphor depend on how familiar the interpreter is with the experience alluded to by the metaphor (Baker \& Partyka, 2012, p. 239)

Below, we will analyse a number of examples of, what we call, "culinary metaphors", i.e. ones based on, e.g. +MEDICINE IS COOKING+, +MEDICINE IS A KITCHEN+, +MEDICINE IS A GARDEN+ metaphorical scenario. The analysis is based on a model repeated here for convenience: 


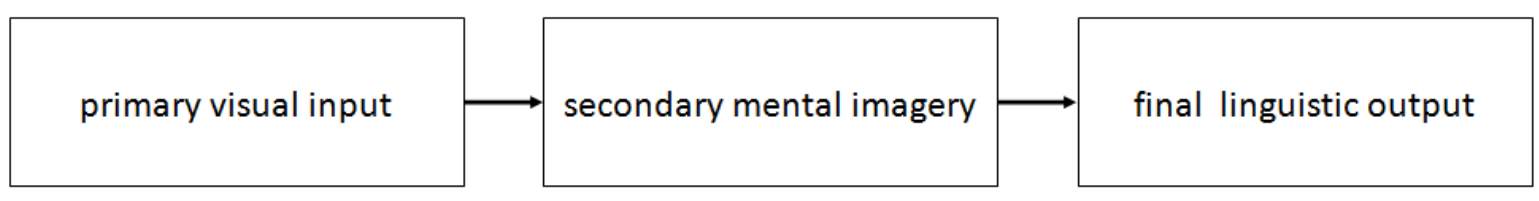

(1) port wine stain
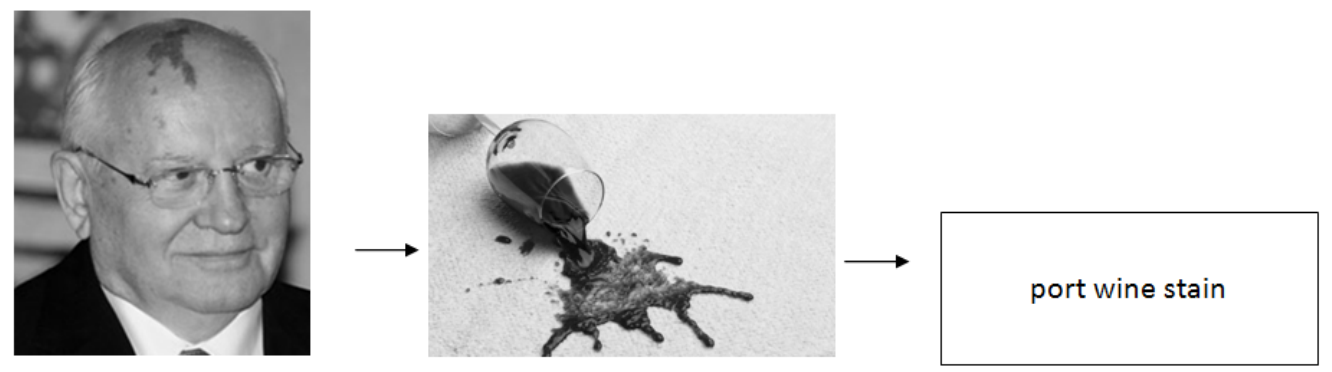

(2) popcorn cell

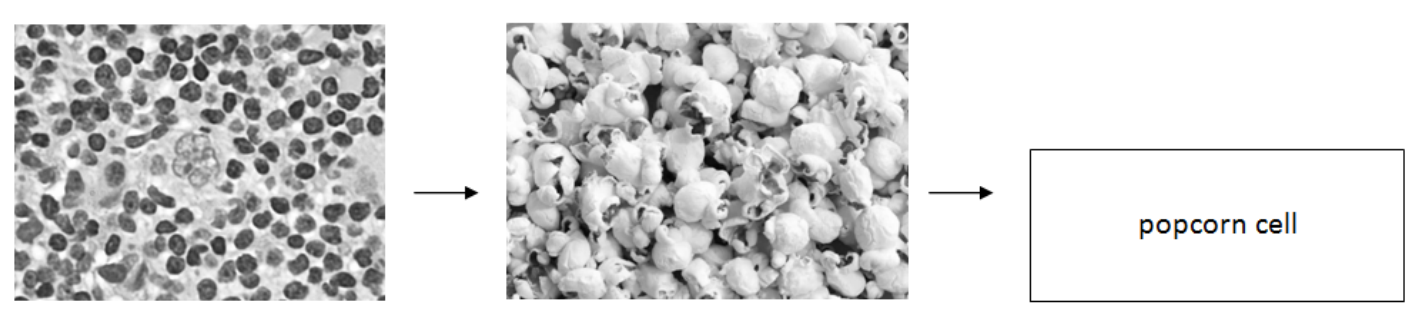

(3) sandwich sign lymphoma
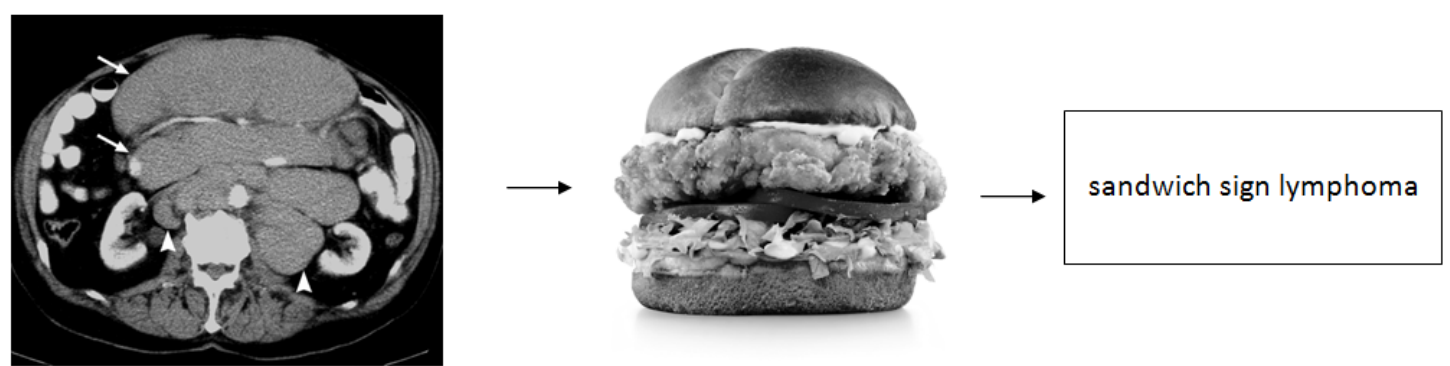

Other examples include:

a) anatomic structures, e.g.: pancake vertebrae, sandwich vertebrae, pancake brain, mulberry molars, blackcurrant rash, cauliflower ear, coffee with milk spots,

b) microscopic images, e.g.: kidney-bean shaped intracellular diplococcic, coffee bean nuclei, doughnut cell, oat cell carcinoma, herringbone pattern, fried egg nuclei, tart cell, banana shaped gametocyte, banana bodies, drumstick appendage, salt and pepper chromatin, Swiss cheese endometrium, bite cell, cornified cells, herringbone pattern, raisin like nucleus, grape bunches (Staphylococcus), berry aneurysm. 


\section{Conclusion}

In the present paper we propose a unitary approach which brings together Lakoff and Johnson's conceptual metaphor theory, and Forceville's pictorial metaphor. We construct a model which can be applied to analyse visual analogies found in medicine in the light of cognitive science. We propose a different view on the pictorial metaphor and multimodality, which, to clarify terminological confusion, we refer to as multiconceptual metaphor. In this view, multimodality does not equal the coexistence of two different modes within one metaphor, but rather understanding one mode in terms of another. We investigate this transfer of information from the visual mode, through the conceptual system, to language. We show a selection of data which highlight the advantages of using metaphors in specialist discourse, didactics in general, and teaching medicine in particular. Radiology is one of the medical fields which benefits most from the employment of metaphors. Visual metaphors used in radiology provide a convenient language of description and useful tool which enhances memorising certain symptoms and signs and as a result, make both diagnosis and learning more effective.

\section{References}

Ahmed, H., Ogala, W.N, Ibrahim, M. (1992). "Culinary metaphors in Western medicine: a dilemma of medical students in Africa.” Medical Education, 26(5), 423-424.

Andrade-Filho de S., \& Pena, G. P. (2001). “Analogies in medicine.” International Journal of Surgical Pathology 2001(9), 345-346.

Baker, S. R. (2014). “Metaphors in Radiology.” Notes of a Radiology Watcher, Springer.

Baker, S.R., \& Partyka, L. (2012). "Relative importance of metaphor in radiology versus other medical specialties." Radiographics, 32(1), 235-40.

Batistatou, A., Zolota, V., \& Scopa, C. D. (2000). “The 'Gourmet' Pathologist.” International Journal of Surgical Pathology, 8, 341-342.

Bewtra, C. (1996). "Food in pathology." American Journal of Dermatopathology 18, 555.

Black, M. (1954). “Metaphor,” Proceedings of the Aristotelian Society, 55, 273-294.

Black, M. (1979). “More about Metaphor,” In A. Ortony (Ed), Metaphor \& Thought.

Bobrova, L., \& Lantolf, J. P. (2012). "Metaphor and Pedagogy." CALPER Working Paper Series, No. 11. The Pennsylvania State University: Center for Advanced Language Proficiency Education and Research.

Canziani, T. (2016). "Metaphors in the mirror: The influence of teaching metaphors in a medical education programme." Language Learning in Higher Education 6(1).

Carter, A. H. (1989). "Metaphors in the physician-patient relationship.” Soundings, 72(1), 153-164.

Carter, S., \& Pitcher, R. (2010). "Extended metaphors for pedagogy: using sameness and difference." Teaching in Higher Education, 15(5), 579-589.

Duncan, S.D., Cassell, J., \& Levy, E.T. (2007). “Gesture and the Dynamic Dimension of Language.” Essays in honor of David McNeill. John Benjamins Publishing Company.

Eviatar, Z., \& Just, M. A. (2006). "Brain correlates of discourse processing: An fMRI investigation of irony and conventional metaphor comprehension.” Neuropsychologia, 44(12), 2348-2359. (accessed on 20/01/2017 at https://www.ncbi.nlm.nih.gov/pmc/articles/PMC1894906/).

Forceville, C. (1996). Pictorial Metaphor in Advertising. Routledge.

Forceville, C. (2007). “A Course in Pictorial and Multimodal Metaphor” (accessed on 15/01/2017 at http://semiot icon.com/sio/courses/pictorial-multimodal-metaphor/).

Forceville, Ch., \& Urios-Aparisi, E. (2009). Multimodal Metaphor. Mouton de Gruyter.

Goldin-Meadow, S. (2003). Hearing gesture: How our hands help us think. Cambridge, MA: Belknap Press of Harvard University Press. 
Herrmann, J. B. (2013). "Metaphor in academic discourse. Linguistic forms, conceptual structures, communicative functions and cognitive representations." (accessed on 12/01/2017 at http://www.lotpublications.nl/Docum ents/333_fulltext.pdf).

Hermann, J. B., and Sardinha, T.B. (Eds.). (2015). Metaphor in Specialist Discourse. John Benjamins Publishing Company.

Hunter, K.M. (1998). "Eating the curriculum." Academic Medicine, 72, 167-172.

Kanthan, R., \& Mills, S. "Using Metaphors, Analogies and Similes as Aids in Teaching Pathology to Medical Students" (accessed on 13/01/2017 at http://www.iamse.org/mse-article/using-metaphors-analogies-andsimiles-as-aids-in-teaching-pathology-to-medical-students/).

Kashkan, G., Provalova, V., Sukhalentceva, N., \& Bayarjargal, E. (2015). "Medical Metaphor as an Instrument of Increasing Performance of International Students from the Preparatory Department." Procedia - Social and Behavioral Sciences 215, 60-66.

Kita, S. (2009). "Cross-cultural variation of speech-accompanying gesture: A review." Language and Cognitive Processes, 24(2), 145-167.

Krennmayr, T. (2011). "Metaphor in newspapers." (accessed on 12/01/2017 at http://www.lotpublications.nl/Doc uments/276_fulltext.pdf).

Kumar K., \& Kumar A. 1994. "Gastronomic pathology." Journal of General Internal Medicine, 9, 207.

Lakhtakia, R. (2014). "Twist of taste: gastronomic allusions in medicine." Medical Humanities, 40, 117-118 doi:10.1136/medhum-2014-010522.

Lakoff, G. (1992). “The Contemporary Theory of Metaphor" (accessed on 20/0/2017 at http://comphacker.org/co mp/engl338/files/2014/02/A9R913D.pdf).

Lakoff, G., \& Johnson, M. (1980). Metaphors We Live By. The University of Chicago Press.

Lakoff, G., \& Johnson, M. (1980b). "Conceptual Metaphor in Everyday Language." The Journal of Philosophy, 77(8), 453-486.

Littlemore, J., \& Low, G. (2006). Figurative Thinking and Foreign Language Learning. Palgrave: Macmillan.

Masukume, G. (2016). "Visual analogies in anatomic and clinical pathology" (accessed 13/01/2016 at https://www.researchgate.net/publication/305388123_Visual_analogies_in_anatomic_and_clinical_patholo gy).

Masukume, G., \& Zumla, A. (2012). "Analogies and metaphors in clinical medicine.” (accessed on 13/01/2016 at https://www.researchgate.net/publication/221868357_Analogies_and_metaphors_in_clinical_medicine).

McNeill, D. 1992. Hand and mind: What gestures reveal about thought. Chicago, IL: University of Chicago Press.

Milam, E. C., Mu, E. W., \& Orlow, S. J. (2015). "Culinary Metaphors in Dermatology: Eating Our Words" in JAMA Dermatology, 151(8), 912.

Mouraz, A., Pereira, A. V., \& Monteiro, R. (2013). "The Use of Metaphors in the Processes of Teaching and Learning in Higher Education." International Online Journal of Educational Sciences, 5(1), 99-110.

Pena, G. P., \& Andrade-Filho de S. (2010). "Analogies in medicine: valuable for learning, reasoning, remembering and naming." Advances in Health Sciences Education, 15(4), 609-619.

Pinar Sanz, M.S. (Ed.). (2015). Multimodality and Cognitive Linguistics. John Benjamins Publishing Company.

Rizutto, A. M. (2001). "Metaphors of a bodily mind." Journal of American Psychoanalytic Association, 49(2), 53568.

Roche, C. J., O'Keeffe, D. P., Lee, W. K., et al. (2002). "Selections from the buffet of food signs in radiology." Radiographics, 22, 1369-1384.

Skorczynska, H. (2013). "Metaphor and education: Reaching business training goals through multimodal metaphor." Procedia - Social and Behavioral Sciences 116, 2344-2351.

Slumasy, D. P. (1993). "What's so special about medicine?" Theoretical Medicine 14, 27-42.

Sontag, S. (1978). Illness as metaphor. New York: McGraw-Hill Ryerson Ltd.

Sontag, S. (1988). Aids and its metaphors. New York.

Spiro, R. T., Feltovitch, P., Coulson, R., \& Anderson, D. (1989). "Multiple analogies for complex concepts: antidotes for analogy-induced misconceptions in advanced knowledge acquisition.” In S. Vosniadou, \& A. Ortony (Eds.), Similarity and analogical reasoning (pp. 498-531). Cambridge: Cambridge University Press.

Tajer, C. D. (2012). “Thinking medicine metaphorically”. Argentine Journal of Cardiology, (80)6. 
Terry, S. I., Hanchard, B. (1979). “Gastrology: the use of culinary terms in medicine.” British Medical Journal, 2, 1636-1639

Wynia, M. (1995). “Culinary Metaphors in Medicine.” Infectious Diseases in Clinical Practice, (4)6, 437-440.

Zawisławska, M. (2011). Metafora w języku nauki. Na przykładzie nauk przyrodniczych. Wydawnictwo Wydziału Polonistyki UW, Warszawa.

\section{Other sources}

foodmedicaleponyms.blogspot.com 